\title{
Food-First Approach to Enhance the Regulation of Post-exercise Skeletal Muscle Protein Synthesis and Remodeling
}

\author{
Nicholas A. Burd ${ }^{1,2} \cdot$ Joseph W. Beals ${ }^{2} \cdot$ Isabel G. Martinez $^{1} \cdot$ Amadeo F. Salvador $^{1} \cdot$ Sarah K. Skinner $^{1}$
}

Published online: 22 January 2019

(c) The Author(s) 2019

\begin{abstract}
Protein recommendations are provided on a daily basis as defined by the recommended dietary allowance (RDA) at $0.80 \mathrm{~g}$ protein $/ \mathrm{kg} / \mathrm{day}$. However, meal-based, as opposed to daily, dietary protein recommendations are likely more informative given the role of the daily protein distribution pattern in modulating the post-exercise muscle protein synthetic response. Current protein meal recommendations to plateau post-exercise muscle protein synthesis rates are based on the ingestion of isolated protein sources, and not protein-rich whole foods. It is generally more common to eat whole food sources of dietary protein within a normal eating pattern to meet dietary protein requirements. Yet, there is a need to define how dietary protein action on muscle protein synthesis rates can be modulated by other nutrients within a food matrix to achieve protein requirements for optimal muscle adaptations. Recent developments suggest that the identification of an "optimal" protein source should likely consider the characteristics of the protein and the food matrix in which it is consumed. This review aims to discuss recent concepts related to protein quality, and the potential interactive effects of the food matrix, to achieve optimal protein requirements and elicit a robust postprandial muscle protein synthetic response with an emphasis on the post-exercise recovery window.
\end{abstract}

\section{Key Points}

Whole protein foods are often more than their constituent amino acids, containing other non-protein nutritive components to facilitate nutrient-nutrient interactions, modulate nutrient behavior, and/or act directly as anabolic signaling molecules.

A food-first approach to post-exercise protein intake will be beneficial for both the skeletal muscle adaptive response and diet quality for most people.

Nicholas A. Burd

naburd@illinois.edu

1 Department of Kinesiology and Community Health, University of Illinois at Urbana-Champaign, 906 S. Goodwin Avenue, Urbana, IL 61801, USA

2 Division of Nutritional Sciences, University of Illinois at Urbana-Champaign, Urbana, IL, USA

\section{Introduction}

The ingestion of protein immediately after exercise [1] and throughout a prolonged recovery period $[2,3]$ is essential to stimulate muscle protein synthesis rates to facilitate remodeling and repair. Muscle protein remodeling, or the dynamic process of synthesis and breakdown, is required to remove and replace damaged proteins with new muscle proteins (reviewed in [4]). It is these exercise-induced increases in protein remodeling that provide the basis for training adaptations that lead to improved physical performance $[5,6]$. While both protein synthesis and breakdown are relevant for muscle mass remodeling, exercise and feeding-induced protein synthesis provide the greatest contribution to the net anabolic response at the muscle level in healthy adults [7-9]. This notion may become more blurred at the whole body level [10]. As such, there has been much interest in the role of protein nutrition in maximizing acute changes in post-exercise muscle protein synthesis rates, and its implication on the long-term muscle adaptive response to exercise training. It is important to note that these exercise-induced increases in muscle protein synthesis rates can facilitate muscle adaptations that are either hypertrophic or nonhypertrophic in nature [4]. 
An area within performance nutrition that has received considerable attention is defining the optimal level of protein intake in a meal to maximally stimulate the post-exercise muscle protein synthetic response. It has been shown that the ingested protein-dose response curves of post-exercise muscle protein synthesis rates reach their breaking points, or plateau, at $\sim 0.25 \mathrm{~g}$ protein $/ \mathrm{kg}$ per meal in healthy young men $[1,11$, 12]. In some cases, ingestion of larger protein amounts were required to induce a plateau on the dose-response curve of muscle protein synthesis rates in young adults [13]. This result was believed to relate to the amount of exercised muscle mass (i.e., full body vs. lower body resistance exercise regimes). Thus, exercise mode, intensity, and duration may differentially impact the post-exercise protein meal requirements to optimize the stimulation of muscle protein synthesis rates $[13,14]$. It is evident that protein requirements are elevated above the protein recommended dietary allowance (RDA; set at $0.8 \mathrm{~g}$ protein/kg/day) when the goal is to optimize post-exercise muscle protein synthesis rates and remodeling [15]. However, the latter point is not surprising as the RDA values are established to prevent deficiencies and, specifically, the protein RDA only represents the minimal daily amount of protein required to consume to prevent net nitrogen (protein) loss in inactive individuals. The protein RDA, therefore, is not set as an "optimal" dietary target to maximize muscle mass. However, it serves as a starting point and helps in the establishment of a more optimal dietary allowance for protein with exercise training.

Currently there are limited data available with regards to the impact of whole food ingestion to contribute protein meal requirements to stimulate post-exercise muscle protein synthesis rates when compared to isolated protein sources. This is relevant as dietary protein is more commonly acquired through whole foods rather than ingesting isolated protein sources during the majority of meal-times. Besides supplying dietary amino acids, protein-dense whole foods often provide other important non-protein components (e.g., lipids, carbohydrates, micronutrients, and other bioactive constituents) within their food matrix that may interact and subsequently contribute to the regulation of muscle protein synthesis rates, and at the same time improve overall diet quality. In this review, we discuss the current understanding and recent advancements of protein quality and the potential contributions of the food matrix to the anabolic milieu and synergistic stimulation of muscle protein synthesis rates and remodeling with an emphasis on the post-exercise recovery period.

\section{Protein Quality}

It is recommended to meet dietary protein intakes by ingesting highly-digestible, high-quality proteins. There are various methods available for protein quality evaluation such as the protein digestibility-corrected amino acid score (PDCAAS) and the digestible indispensable amino acid score (DIAAS) to reference proteins according to their ability to deliver target intakes of indispensable amino acids. For the past two decades, PDCAAS has been used to estimate food protein quality [16]. However, the Food and Agriculture Organization (FAO) currently recommends the DIAAS procedure [16], which takes into account that the digestibility of amino acids should be directly determined at the end of the small intestine (true ileal digestibility) and is commonly performed in growing pigs. DIAAS is an improvement upon PDCAAs that estimates protein quality based on total tract fecal digestibility with the use of rats as its model [17]. Table 1 lists the DIAAS and PDCAAS of several isolated proteins and protein dense foods. Based on the listed protein quality scores, it is evident that DIAAS improves upon PDCAAS by not truncating scores at 1.0 as well as circumventing other flaws [17-19]. As such, DIAAS should allow for an improved ranking system to avoid underestimating the anabolic potential of high(er)-quality proteins.

While DIAAS provides a better method to define protein quality in terms of the relative digestible content of the IAAs and the amino acid requirement, much of the research into DIAAS is limited to isolated protein sources and/or raw feedstuffs for livestock production. This is noteworthy as cooking (heat treatment) of protein foods can modify digestive kinetics and metabolism of dietary proteins [20, 21]. In addition, DIAAS does not attempt to consider how the scores translate into optimizing more downstream physiological targets of interest to a physically active person or athlete. The primary metabolic action of dietary proteinderived amino acids is to stimulate whole body and muscle protein synthesis to support a positive net protein balance [22]. As such, it is important to couple assessments of dietary protein quality with other metabolic correlates, such as protein synthesis, in order to more comprehensively characterize the anabolic potential of dietary proteins to augment the quality and quantity of muscle protein. Moreover, it has been demonstrated that exercise may directly impact protein digestibility and the subsequent release of dietary protein derived amino acids into the circulation [23]. Thus, it is likely important to consider the consequences of prior exercise on protein digestibility/quality especially for more physically active populations such as athletes involved in regular training or competition.

The invasive nature of determining DIAAS in vivo in humans precludes the ability of this method to be coupled with an exercise setting [24]. As such, identifying approaches that are more readily adaptable to an exercising human to allow for assessment of protein digestibility would be useful, especially given the interactive nature of protein nutrition and exercise on whole body and muscle protein metabolic responses. Intrinsic labeling of protein foods with 
Table 1 Digestible indispensable amino acid score (DIAAS) and protein digestibility-corrected amino acid score (PDCASS) for isolated proteins and whole foods

DIAAS $^{\mathrm{a}} \begin{aligned} & \text { PDCAAS } \\ & {\text { (nontruncated })^{\mathrm{b}}}^{\mathrm{b}} \text { References }^{\mathrm{c}}\end{aligned}$

\begin{tabular}{|c|c|c|c|}
\hline \multicolumn{4}{|l|}{ Animal-derived foods } \\
\hline Whey protein isolate $\mathrm{e}^{\mathrm{e}}$ & 1.00 & 0.99 & [17] \\
\hline Whey protein concentrate & 1.07 & $1.00(1.07)$ & [17] \\
\hline Milk protein concentrate ${ }^{\mathrm{e}}$ & 1.20 & $1.00(1.21)$ & [17] \\
\hline Skimmed milk protein ${ }^{\mathrm{e}}$ & 1.05 & $1.00(1.12)$ & [17] \\
\hline Whole milk powder ${ }^{\mathrm{e}}$ & 1.16 & $1.00(1.16)$ & {$[66]$} \\
\hline Casein $^{\mathrm{e}, \mathrm{f}}$ & 1.09 & $1.00(1.20)$ & {$[67,68]$} \\
\hline Cow milk ${ }^{\mathrm{e}}$ & 1.16 & & {$[66]$} \\
\hline Sheep milk ${ }^{\mathrm{e}}$ & 1.09 & & {$[66]$} \\
\hline Goat milk ${ }^{\mathrm{e}}$ & 1.24 & & {$[66]$} \\
\hline Whole egg, boiled ${ }^{\mathrm{e}}$ & 1.13 & $1.00(1.05)$ & {$[66]$} \\
\hline $\mathrm{Beef}^{\mathrm{e}}$ & 1.12 & $1.00(1.14)$ & [69] \\
\hline Pork $^{\mathrm{e}}$ & 1.14 & 1.00 & {$[66]$} \\
\hline Chicken breast $^{\mathrm{e}}$ & 1.08 & $1.00(1.01)$ & {$[66]$} \\
\hline Tilapia (fish) ${ }^{\mathrm{d}}$ & 1.00 & & [69] \\
\hline \multicolumn{4}{|l|}{ Non-animal-derived foods } \\
\hline Soya protein isolate ${ }^{\mathrm{e}}$ & 0.84 & 0.93 & [17] \\
\hline Soya flour ${ }^{\mathrm{e}}$ & 0.89 & 0.98 & [17] \\
\hline Wheat $^{\mathrm{e}}$ & 0.45 & 0.50 & [17] \\
\hline Pea protein concentrate ${ }^{\mathrm{e}}$ & 0.62 & 0.75 & [17] \\
\hline Cooked peas ${ }^{\mathrm{f}}$ & 0.58 & 0.60 & {$[70]$} \\
\hline Oat protein concentrate ${ }^{\mathrm{e}}$ & 0.67 & 0.69 & [71] \\
\hline Cooked rolled oats ${ }^{\mathrm{f}}$ & 0.54 & 0.67 & {$[70]$} \\
\hline Rice protein concentrate ${ }^{f}$ & 0.37 & 0.42 & {$[70]$} \\
\hline Cooked rice ${ }^{f}$ & 0.60 & 0.62 & {$[70]$} \\
\hline Rye $^{\mathrm{e}}$ & 0.48 & 0.59 & [69] \\
\hline Barley $^{\mathrm{e}}$ & 0.47 & 0.59 & [69] \\
\hline Peas $^{\mathrm{e}}$ & 0.65 & 0.79 & [69] \\
\hline Sorghum ${ }^{\mathrm{e}, \mathrm{f}}$ & 0.29 & 0.29 & {$[72,73]$} \\
\hline Cooked kidney beans ${ }^{\mathrm{f}}$ & 0.59 & 0.65 & [70] \\
\hline Roasted peanuts ${ }^{\mathrm{f}}$ & 0.43 & 0.51 & {$[70]$} \\
\hline $\begin{array}{l}\text { Corn based breakfast } \\
\text { cereal }^{\mathrm{f}}\end{array}$ & 0.01 & 0.08 & {$[70]$} \\
\hline
\end{tabular}

Only values that used the scoring patterns for children older than 3 years, adolescents, and adults were selected

${ }^{a}$ Values for DIAAS were calculated from the ileal digestibility of amino acids

${ }^{b}$ Values for PDCAAS were calculated from the total tract digestibility of crude protein

${ }^{c}$ All values for DIAAS and PDCAAS were selected in humans, if available, growing pigs, or in growing rats in that order

${ }^{\mathrm{d}}$ Measured in humans

${ }^{\mathrm{e}}$ Measured in pigs

${ }^{\mathrm{f}}$ Measured in rats

stable isotope amino acids has been useful to provide an index of food protein digestibility against the background of exercise in vivo in humans [25-27]. This method combines primed constant infusion methods with specifically produced labeled food proteins to assess the amount and speed of release of dietary protein derived amino acids in the circulation. Table 2 lists the different protein foods that have been intrinsically labeled to determine the amount of dietary protein-derived amino acids (usually leucine or phenylalanine) that appeared in the circulation, expressed as a percentage, after their ingestion. It is important to recognize that the amino acid labeled in the ingested food may have a direct impact on the amino acid availability expressed in Table 2. For example, it has been shown that there are differences in postprandial splanchnic handling of leucine versus phenylalanine [28], which impacts their appearance rates and concentrations in the blood. In general, there is greater selective splanchnic uptake of phenylalanine when compared to leucine. Overall, plasma dietary amino acid availability measurements can be coupled with measurements of muscle protein synthesis rates to provide additional insight into the anabolic potential of the ingested food (Table 2).

It is clear that there is limited information on how a wide variety of protein food sources stimulate postprandial muscle protein synthesis rates. Moreover, the majority of studies that have assessed the impact of protein nutrition on the stimulation of postprandial muscle protein synthesis rates have focused on isolated protein sources [29-31]. Based on these studies of isolated protein sources, such as isolated whey, micellar casein, and soy fractions [29, 32], the leucine "trigger" hypothesis was developed (Fig. 1). This leucine trigger hypothesis suggests that a rapid rise (within $\sim 60-90 \mathrm{~min}$ ) in blood leucine concentrations in close temporal proximity to an exercise bout after protein ingestion is most anabolic for stimulating post-exercise muscle protein synthesis rates, as observed with ingestion of leucine-rich isolated protein sources (Fig. 1). However, it would seem likely that there is not an absolute blood leucine concentration that serves as a "maximum switch on" for the post-exercise muscle protein synthetic response, but rather a step-wise increase in muscle protein synthesis rates with increasing blood leucine concentrations, which would lead to an eventual plateau in muscle protein synthesis rates with higher ingested protein amounts [1]. Interestingly, however, the ingestion of whole foods is also potent for the stimulation of post-exercise muscle protein synthesis rates despite not facilitating a rapid rise in leucinemia during the immediate post-exercise period [33]. Specifically, the ingestion of protein-dense whole foods results in a prolonged release of dietary amino acids into the circulation with plasma amino acid concentration values peaking at $\sim 120$ min of the postprandial period in healthy adults [34]. Thus, the leucine "trigger" hypothesis may be more relevant after the ingestion of isolated protein sources as opposed to whole food sources of protein. Specifically, other non-protein components within the whole food matrix may likely influence the regulation of post-exercise muscle 
Table 2 Protein-derived amino acid availability in the circulation and postprandial rates of muscle protein synthesis (MPS) after ingestion of isolated protein sources and whole foods healthy young and older adults

\begin{tabular}{|c|c|c|c|c|}
\hline & $\begin{array}{l}\text { Protein } \\
\text { amount }(\mathrm{g})\end{array}$ & $\begin{array}{l}\text { Dietary amino acid } \\
\text { availability }^{\mathrm{a}}\end{array}$ & MPS response ${ }^{b}$ & References \\
\hline \multicolumn{5}{|c|}{ Intrinsically labeled food studies } \\
\hline Casein & 20 & $55 \%$ (Phe) & $1.51^{\mathrm{d}}$ & [74] \\
\hline Beef $^{c}$ & 30 & $64 \%(\mathrm{Phe})$ & $1.90^{\mathrm{d}}$ & {$[33]$} \\
\hline Egg white ${ }^{c}$ & 18 & $66 \%$ (Leu) & $1.90^{\mathrm{e}}$ & {$[35]$} \\
\hline Whey & 35 & $59 \%$ (Phe) & $2.09^{\mathrm{d}}$ & [75] \\
\hline Skim milk ${ }^{\mathrm{c}}$ & 30 & $57 \%$ (Phe) & $2.37^{\mathrm{d}}$ & {$[33]$} \\
\hline Whole egg ${ }^{\mathrm{c}}$ & 18 & $68 \%$ (Leu) & $2.70^{\mathrm{e}}$ & {$[35]$} \\
\hline Whey & 20 & $58 \%$ (Phe) & No basal & [76] \\
\hline Casein & 20 & $53 \%$ (Phe) & No basal & [76] \\
\hline Casein hydrolysate & 20 & $55 \%$ (Phe) & No basal & [76] \\
\hline \multicolumn{5}{|l|}{ Non-labeled food studies } \\
\hline Wheat protein hydrolysate & 60 & & $1.40^{\mathrm{d}}$ & {$[31]$} \\
\hline Soy $^{\mathrm{c}}$ & 40 & & $1.40^{\mathrm{d}}$ & [77] \\
\hline Pork & 36 & & $1.63^{\mathrm{d}}$ & [34] \\
\hline $\mathrm{Beef}^{\mathrm{c}}$ & 36 & & $2.00^{\mathrm{d}}$ & [78] \\
\hline Milk protein concentrate & 20 & & $2.48^{\mathrm{d}}$ & [79] \\
\hline Whey & 20 & & $3.00^{\mathrm{d}}$ & [79] \\
\hline
\end{tabular}

${ }^{a}$ Fractions of dietary protein derived amino acids that appeared in the circulation (percentage) throughout $0-5 \mathrm{~h}$ or $0-6 \mathrm{~h}$ postprandial periods. The data were based on an orally ingested leucine (Leu) or phenylalanine (Phe) tracers intrinsically labeled into food sources and designated by their respective amino acid in parentheses

${ }^{b}$ Postprandial rates of MPS expressed as fold change from reported basal rates (when available)

${ }^{\mathrm{c}}$ Indicates protein ingestion after an acute bout of exercise

${ }^{\mathrm{d}}$ Indicates rates of MPS were measured using labeled phenylalanine tracer incorporation in muscle tissue

${ }^{\mathrm{e}}$ Indicates rates of MPS were calculated using labeled leucine tracer incorporation into muscle tissue protein synthesis rates $[33,35]$. Nonetheless, there is still much to learn with respect to how food matrices containing protein interact to affect protein quality/digestibility and its implications for the post-exercise stimulation of muscle protein synthesis rates (discussed in Sect. 3).

\section{Food Matrix}

In general, the nutritional quality of food is primarily based on the relative quantities of each individual nutritional component (e.g., protein, carbohydrates, lipids, and micronutrients). This notion has certainly been true when assessing the role of dietary protein in post-exercise muscle remodeling processes in humans as most studies have used isolated protein fractions. It has been shown that amino acids, particularly the essential amino acids [36], have potent anabolic properties towards the stimulation of muscle protein synthesis rates in vivo in humans. However, the holistic properties of foods and their potential influence on post-exercise muscle protein remodeling and repair has not been extensively studied. The food matrix refers to the overall chemical dynamics of food, which includes how various food components are structured and interact [37]. Emerging evidence seems to suggest there are potential interactions occurring within a food matrix (i.e., food synergy [38]) that modulate various metabolic processes (including muscle protein synthesis). In other words, the ingestion of specific whole foods, and the associated nutrient-nutrient interactions, possibly facilitates a stronger anabolic effect than the individual actions from each individual food component.

Elliot et al. [39] demonstrated that whole milk ingestion (627 kcals; $8 \mathrm{~g}$ protein, $8 \mathrm{~g}$ fat, and $11 \mathrm{~g}$ carbohydrate) consumed $1 \mathrm{~h}$ after resistance exercise stimulated greater amino acid uptake across the leg when compared to fat-free milk ( $377 \mathrm{kcals} ; 9 \mathrm{~g}$ protein, $0.6 \mathrm{~g}$ fat, and $12 \mathrm{~g}$ carbohydrate) or iso-caloric amounts of fat-free milk (626 kcals; $14.5 \mathrm{~g}$ protein, $1 \mathrm{~g}$ fat, and $20 \mathrm{~g}$ carbohydrate) in healthy men and women. Likewise, van Loon's research group demonstrated a differential temporal stimulation of post-exercise muscle protein synthesis rates after ingestion of skim milk (30 g protein, $31 \mathrm{~g}$ carbohydrate, and $0.4 \mathrm{~g}$ fat) versus iso-nitrogenous amounts of beef ( $30 \mathrm{~g}$ protein, $0.7 \mathrm{~g}$ carbohydrate, and $4.6 \mathrm{~g}$ fat) in young men [33]. Specifically, this work demonstrated that skim milk ingestion elicited a greater stimulation of post-exercise muscle protein synthesis rates during the early ( $0-2 \mathrm{~h}$ ) recovery phase when compared to beef ingestion. The greater anabolic potential on muscles during the early 


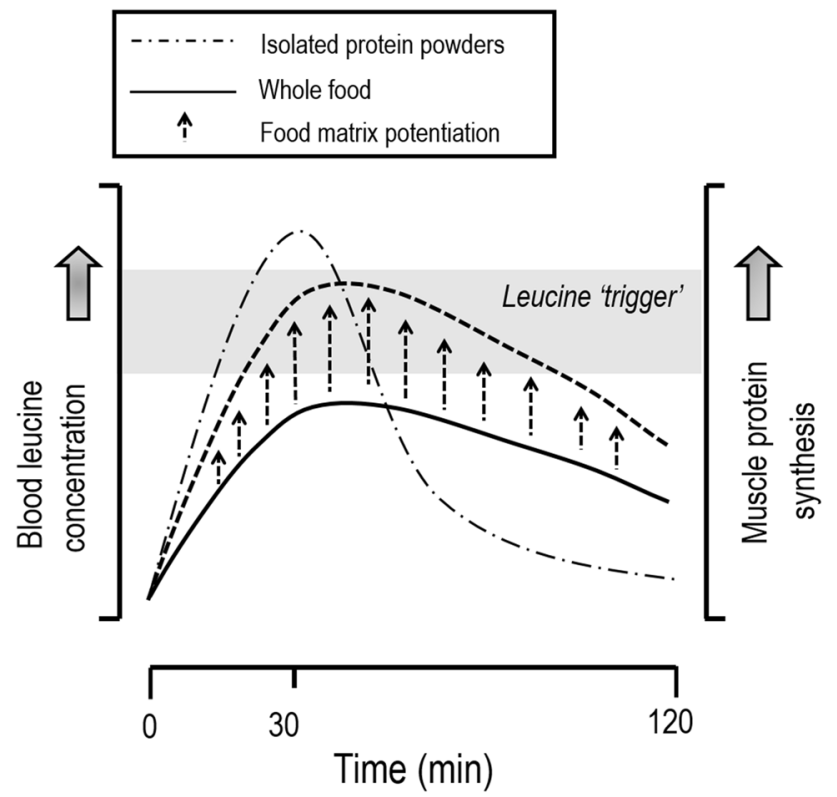

Fig. 1 The "leucine trigger" hypothesis. The ingestion of an isolated protein source (e.g., whey) results in a rapid rise in plasma leucine concentrations, which is superior in terms of amplitude when compared to whole food sources of protein, and corresponds to the extent of stimulation of muscle protein synthesis rates [29]. However, we hypothesize that the interaction of non-protein nutritive components with dietary amino acids (food matrix effects) has a direct effect on post-exercise muscle protein synthesis rates. Overall, the leucine trigger hypothesis is probably highly relevant when ingesting isolated protein fractions, but is less applicable towards the muscle protein synthetic response when ingesting whole food sources of protein, especially in healthy adults $[33,35]$

recovery period after skim milk ingestion occurred despite beef ingestion inducing a more rapid protein digestion and amino acid absorption rates, which ultimately facilitated more dietary amino acids being available in the circulation in the beef condition [33]. These data are interesting as they highlight that commonly assumed anabolic characteristics of an ingested protein source, such as the higher peak amplitude of leucinemia with beef ingestion, do not universally translate into a greater early muscle protein synthetic response when compared to whole food (milk) ingestion in healthy young men.

From these studies, it is not possible to elucidate the food component(s), or mechanism, within the dairy matrix that may have contributed to the differential regulation of post-exercise muscle protein synthesis rates between the ingested food sources. Interestingly, studies have demonstrated that co-ingestion of micellar casein with individual food components such as milk fat [40], carbohydrates [41], or milk serum ([42]; mixture of $10 \%$ lactose, $0.3 \%$ protein, $0.06 \%$ fat, and $1.1 \%$ minerals) does not further augment the postprandial muscle protein synthetic response when compared to ingestion of micellar casein alone. It is worth noting, however, that these studies were conducted at rest, and perhaps an exercise stimulus may be required to create a more physiologically relevant interaction between dietary amino acids and the non-protein components of the whole food at the muscle level. Nonetheless, it would seem that superior post-exercise muscle protein synthetic responses observed with whole milk [39] or skim milk [33] ingestion were not related to these specific food components. Instead, it is possible that the specific effect of a dairy matrix on the regulation of post-exercise muscle protein synthesis rates cannot be attributed to an individual nutrient and is dependent on the sum and interaction of all its nutrients. Moreover, a dairy matrix may differ between specific dairy products (full-fat vs. low-fat products such as yogurt, cheese, etc.) and between products produced from grass-fed versus grain-fed dairy cows [43]. For example, it has been suggested ingesting milk collected from grass-fed cows may confer greater health benefits (i.e., reduced risk of cardiovascular disease) when compared to milk collected from grain-fed dairy cows likely due to the manipulation of the fatty acid composition of the dairy matrix [44]. Thus, it is likely possible to manipulate the matrix of foods either with food fortification techniques or directly by altering feeding approaches within cows to impact human health.

Our research group has recently contributed to the concept that food matrix effects may influence the postexercise stimulation of muscle protein synthesis rates and remodeling. Specifically, we assessed the impact of the ingestion of whole eggs or iso-nitrogenous amounts of egg whites on the stimulation of muscle protein synthesis rates during recovery from resistance exercise in healthy young men [35]. We demonstrated that the post-exercise muscle protein synthetic response was more strongly stimulated after the ingestion of whole eggs versus egg whites. Interestingly, the difference in the post-exercise stimulation of muscle protein synthesis rates between the whole egg and egg white conditions was not related to the postprandial plasma leucine availability, plasma insulin concentrations, muscle amino acid transporter content, uptake of dietary leucine into muscle, or muscle anabolic signaling pathway phosphorylation [35]. Indeed, the egg white consists of water and protein with the remainder consisting of trace amounts of carbohydrate and lipids. However, the whole egg consists of a food matrix that is rich in high quality protein, lipids, vitamins, and minerals. More work is required to confirm, but it is interesting to speculate that the whole egg matrix may be interacting to create a food synergy to support a greater post-exercise muscle protein synthetic response when compared to the egg white. For example, Fig. 2 illustrates the food components within the white and yolk portions of a whole egg and their potential contribution to the stimulation of postexercise muscle protein synthesis rates. It is evident that 
proteins (amino acids) are the main precursors for muscle protein synthesis; however, other non-protein components may influence how dietary amino acids are used for protein synthesis by aiding in protein translation. Similar to dairy products, the egg matrix can also be altered through manipulation of either feed composition [45] or living conditions (cage-raised or free-range [46]) of laying hens.

Overall, the significance of food matrix manipulations and nutrient-nutrient interactions for the post-exercise stimulation of muscle protein synthesis rates is not known. However, it is important to identify more sustainable strategies for protein nutrition in modern society to compensate for the increased demand from a growing population [47] and the apparent elevated protein meal requirements to maximize muscle protein anabolism especially in people with active lifestyles $[1,13]$ when compared to the protein RDA. The ingestion of whole foods, with a matrix rich in dietary proteins, macro- and micro-nutrients, may be a potential dietary strategy to more efficiently utilize dietary amino acids for postprandial muscle protein accretion. However, this hypothesis still requires rigorous testing.

\section{Exercise, Gut Permeability, and Implications of the Food Matrix}

Exercise has the potential to directly impact gastrointestinal (GI) function. This is significant as proper GI function is necessary to sustain exercise performance as well as promote substrate delivery to support glycogen re-synthesis and protein synthesis during recovery from exercise. An abundance of evidence has demonstrated that there is reduced GI barrier function (permeability) and potentially mucosal disruption as a result of acute exercise [14, 23, 48-58]. These finding of alterations in GI physiology have been demonstrated in a variety of settings including running [14, 49, 50, 52, 57, 58], cycling [48, 53-56], resistance exercise [23], and prolonged endurance exercise [51]. Moreover, there appears to be an effect of exercise intensity on the magnitude of the increased GI permeability [57]. These alterations in GI physiology appear to be related to splanchnic hypo-perfusion during the bout of exercise [56]. Also, a recent study indicated that mucosal disruption may explain some, but not all, of the exercise-induced alterations in intestinal permeability [49]. Evidence suggests, however, that food/nutrient ingestion may lead to improvements in the GI permeability response

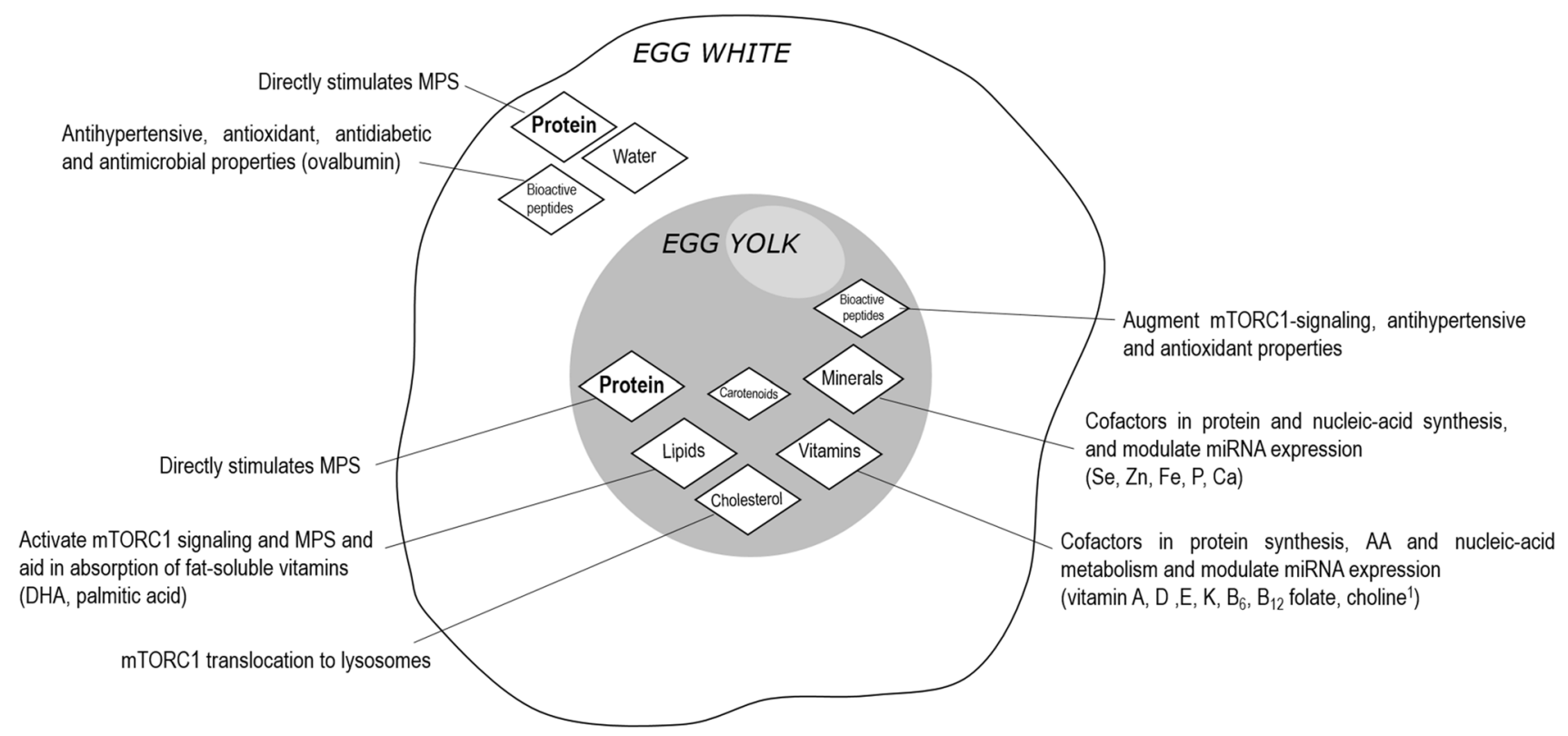

Fig. 2 The whole egg matrix is rich in high-quality dietary protein, lipids, vitamins, and minerals when compared to the egg white matrix. While dietary amino acids are the main precursors for protein synthesis, the non-protein components of the whole egg, which are largely contained in the yolk, may have a role in various aspects of the regulation of muscle protein synthesis rates (MPS). These nonprotein components include: cholesterol being involved in translocation of mTORC1 to the lysosomes [80], lipids [81], vitamins [82, 83], minerals [84], and other bioactive components [85, 86] serving to facilitate nutrient sensing mechanisms in muscle tissue. Thus, the interaction of nutrients within whole foods to support post-exercise MPS is likely greater than each respective nutrient in isolation. We propose that food matrix effects should be considered when defining optimal protein intakes to stimulate post-exercise MPS and remodeling. mTORC1 mammalian target of rapamycin complex 1, DHA docosahexaenoic acid, miRNA micro-ribonucleic acid, $A A$ amino acids.

${ }^{1}$ Indicates vitamin-like nutrient 
to exercise $[14,52,54]$. Specifically, increased concentrations of small intestine-derived fatty acid binding protein (I-FABP), which is often used as a bio-marker of intestinal injury, in the circulation are detectable for several hours during recovery from a 2-h bout of treadmill running [52] or after moderate intensity cycling [54]. By contrast, when food is consumed post-exercise, GI permeability returned to baseline much more rapidly [14]. In fact, when nutrition is consumed concurrently with exercise, it has been shown that gut damage markers are unaltered during or after $2 \mathrm{~h}$ of treadmill running as compared with consuming only water [52]. It has also been previously demonstrated that nutrient provision can ameliorate altered gut barrier function and prevent epithelial apoptosis [59]. Collectively, these data highlight that there is likely an interplay between exercise and the gut, which will likely affect the handling of nutrition during recovery from exercise.

What is noteworthy is that exercise prior to food ingestion has the potential to alter food digestion and absorption of nutrients within the food matrix. For example, it has been shown that large food-derived peptides can cross the epithelial barrier during and after exercise [53], which is uncharacteristic of normal digestion [60]. Thus, exercise has the potential to create an avenue, via increased gut permeability, for bio-active food constituents, or non-protein components, within a food matrix to enter the circulation. In addition to this, small pieces of genetic regulatory material (microRNAs and RNA) have been shown to survive digestion [61-63], which may be elevated during acute exercise recovery due to greater GI permeability. Importantly, these compounds have demonstrable effects on gene expression in host cells [62, 64]. However, there is a great deal of research still needed in this area to better define how exercise may assist in the transfer of large peptides, and/or non-nutrient food components, after food ingestion and their effects during post-exercise recovery.

\section{Conclusion}

Dietary protein ingestion immediately after exercise [65] and throughout a prolonged recovery ( $\geq 1$ day [2]) further increases muscle protein synthesis rates to facilitate nonhypertrophic or hypertrophic protein remodeling when compared to feeding alone. Current protein recommendations to maximize the post-exercise muscle protein synthetic response are based on isolated protein sources, but suggest that protein meal requirements are elevated when compared to the protein RDA $[1,12,13]$. Recent studies demonstrate a developing role of the food matrix in modulating the postexercise muscle protein synthetic response [33, 35]. Specifically, it seems that the ingestion of protein-dense whole foods, and the interaction of their non-protein nutritive components, can likely potentiate the use of dietary amino acids for post-exercise muscle protein synthesis rates. However, it is unknown whether different food matrices (e.g., dairy matrix vs. egg matrix), fortification of a food matrix (e.g., manipulation of lipid, vitamin, or mineral content), or food combinations can be utilized to differentially impact the post-exercise muscle protein synthetic response and overall protein requirement. Moreover, exercise and its subsequent impact on increased GI permeability may facilitate the transfer of non-protein components and protein peptides within the food matrix to modulate the post-exercise muscle adaptive response [53]. Thus, a food-first approach to postexercise protein intake will be beneficial for both the skeletal muscle adaptive response and diet quality for most people. Ultimately, sports dietitians will need to consider the typical eating pattern (animal- vs. plant-based diets) and travel/ training schedule of an athlete when developing meal plans as this is necessary when identifying whether to incorporate whole foods, dietary supplements, or both.

Acknowledgements This supplement is supported by the Gatorade Sports Science Institute (GSSI). The supplement was guest edited by Lawrence L. Spriet, who attended a meeting of the GSSI Expert Panel in October 2017 and received honoraria from the GSSI, a division of PepsiCo, Inc., for his participation in the meeting. He received no honoraria for guest editing the supplement. Dr. Spriet suggested peer reviewers for each paper, which were sent to the Sports Medicine Editor-in-Chief for approval prior to being approached. Dr. Spriet provided comments on each paper and made an editorial decision based on comments from the peer reviewers and the Editor-in-Chief. Where decisions were uncertain, Dr. Spriet consulted with the Editor-in-Chief.

\section{Compliance with Ethical Standards}

Funding Nicholas Burd attended a meeting of the GSSI Expert Panel in October 2017 and received honoraria from the GSSI for his meeting participation and writing of this manuscript. In addition, Nicholas Burd receives research support from the National Cattlemen's Beef Association and Alliance for Potato Research \& Education (APRE). No other sources of funding were used to assist in the preparation of this review.

Conflicts of Interest Nicholas Burd, Joseph Beals, Isabel Martinez, Amadeo Salvador and Sarah Skinner declare they have no conflicts of interest relevant to the content of this review.

Open Access This article is distributed under the terms of the Creative Commons Attribution 4.0 International License (http://creativeco mmons.org/licenses/by/4.0/), which permits unrestricted use, distribution, and reproduction in any medium, provided you give appropriate credit to the original author(s) and the source, provide a link to the Creative Commons license, and indicate if changes were made.

\section{References}

1. Moore DR, Robinson MJ, Fry JL, Tang JE, Glover EI, Wilkinson $\mathrm{SB}$, et al. Ingested protein dose response of muscle and albumin protein synthesis after resistance exercise in young men. 
Am J Clin Nutr. 2009;89(1):161-8. https://doi.org/10.3945/ ajcn.2008.26401.

2. Burd NA, West DW, Moore DR, Atherton PJ, Staples AW, Prior T, et al. Enhanced amino acid sensitivity of myofibrillar protein synthesis persists for up to $24 \mathrm{~h}$ after resistance exercise in young men. J Nutr. 2011;141(4):568-73. https://doi.org/10.3945/ jn. 110.135038 .

3. Wall BT, Burd NA, Franssen R, Gorissen SH, Snijders T, Senden $\mathrm{JM}$, et al. Presleep protein ingestion does not compromise the muscle protein synthetic response to protein ingested the following morning. Am J Physiol Endocrinol Metab. 2016;311(6):E964 73. https://doi.org/10.1152/ajpendo.00325.2016.

4. Burd NA, De Lisio M. Skeletal muscle remodeling: interconnections between stem cells and protein turnover. Exerc Sport Sci Rev. 2017;45(3):187-91. https://doi.org/10.1249/jes.0000000000 000117.

5. Tang JE, Hartman JW, Phillips SM. Increased muscle oxidative potential following resistance training induced fibre hypertrophy in young men. Appl Physiol Nutr Metab. 2006;31(5):495-501. https://doi.org/10.1139/h06-026.

6. Hartman JW, Tang JE, Wilkinson SB, Tarnopolsky MA, Lawrence RL, Fullerton AV, et al. Consumption of fat-free fluid milk after resistance exercise promotes greater lean mass accretion than does consumption of soy or carbohydrate in young, novice, male weightlifters. Am J Clin Nutr. 2007;86(2):373-81.

7. Staples AW, Burd NA, West DW, Currie KD, Atherton PJ, Moore DR, et al. Carbohydrate does not augment exercise-induced protein accretion versus protein alone. Med Sci Sports Exerc. 2011;43(7):1154-61. https://doi.org/10.1249/mss.0b013e3182 $0751 \mathrm{cb}$.

8. Phillips SM, Tipton KD, Aarsland A, Wolf SE, Wolfe RR. Mixed muscle protein synthesis and breakdown after resistance exercise in humans. Am J Physiol. 1997;273(1 Pt 1):E99-107.

9. Phillips SM, Tipton KD, Ferrando AA, Wolfe RR. Resistance training reduces the acute exercise-induced increase in muscle protein turnover. Am J Physiol. 1999;276(1 Pt 1):E118-24.

10. Kim IY, Deutz NEP, Wolfe RR. Update on maximal anabolic response to dietary protein. Clin Nutr. 2018;37(2):411-8. https:// doi.org/10.1016/j.clnu.2017.05.029.

11. Moore DR, Churchward-Venne TA, Witard O, Breen L, Burd NA, Tipton KD, et al. Protein ingestion to stimulate myofibrillar protein synthesis requires greater relative protein intakes in healthy older versus younger men. J Gerontol A Biol Sci Med Sci. 2015;70(1):57-62. https://doi.org/10.1093/gerona/glu103.

12. Witard OC, Jackman SR, Breen L, Smith K, Selby A, Tipton KD. Myofibrillar muscle protein synthesis rates subsequent to a meal in response to increasing doses of whey protein at rest and after resistance exercise. Am J Clin Nutr. 2014;99(1):86-95. https:// doi.org/10.3945/ajen.112.055517.

13. Macnaughton LS, Wardle SL, Witard OC, McGlory C, Hamilton $\mathrm{DL}$, Jeromson $\mathrm{S}$, et al. The response of muscle protein synthesis following whole-body resistance exercise is greater following $40 \mathrm{~g}$ than $20 \mathrm{~g}$ of ingested whey protein. Physiol Rep. 2016. https://doi. org/10.14814/phy2.12893.

14. Mazzulla M, Parel JT, Beals JW, Vanv S, Abou Sawan S, West DWD, et al. Endurance exercise attenuates postprandial wholebody leucine balance in trained men. Med Sci Sports Exerc. 2017;49(12):2585-92. https://doi.org/10.1249/mss.0000000000 001394.

15. Phillips SM, Chevalier S, Leidy HJ. Protein "requirements" beyond the RDA: implications for optimizing health. Appl Physiol Nutr Metab. 2016;41(5):565-72. https://doi.org/10.1139/ apnm-2015-0550.

16. Consultation FE. Dietary protein quality evaluation in human nutrition. 2013.
17. Mathai JK, Liu Y, Stein HH. Values for digestible indispensable amino acid scores (DIAAS) for some dairy and plant proteins may better describe protein quality than values calculated using the concept for protein digestibility-corrected amino acid scores (PDCAAS). Br J Nutr. 2017;117(4):490-9. https://doi. org/10.1017/s0007114517000125.

18. Wolfe RR, Rutherfurd SM, Kim IY, Moughan PJ. Protein quality as determined by the Digestible Indispensable Amino Acid Score: evaluation of factors underlying the calculation. Nutr Rev. 2016;74(9):584-99. https://doi.org/10.1093/nutrit/nuw022.

19. Phillips SM. Current concepts and unresolved questions in dietary protein requirements and supplements in adults. Front Nutr. 2017;4:13. https://doi.org/10.3389/fnut.2017.00013.

20. Lacroix M, Bon C, Bos C, Leonil J, Benamouzig R, Luengo C, et al. Ultra high temperature treatment, but not pasteurization, affects the postprandial kinetics of milk proteins in humans. J Nutr. 2008;138(12):2342-7. https://doi.org/10.3945/jn.108.09699 0 .

21. Evenepoel P, Geypens B, Luypaerts A, Hiele M, Ghoos Y, Rutgeerts P. Digestibility of cooked and raw egg protein in humans as assessed by stable isotope techniques. J Nutr. 1998;128(10):1716-22.

22. Biolo G, Tipton KD, Klein S, Wolfe RR. An abundant supply of amino acids enhances the metabolic effect of exercise on muscle protein. Am J Physiol. 1997;273(1 Pt 1):E122-9.

23. van Wijck K, Pennings B, van Bijnen AA, Senden JM, Buurman WA, Dejong $\mathrm{CH}$, et al. Dietary protein digestion and absorption are impaired during acute postexercise recovery in young men. Am J Physiol Regul Integr Comp Physiol. 2013;304(5):R356-61. https://doi.org/10.1152/ajpregu.00294.2012.

24. Deglaire A, Bos C, Tome D, Moughan PJ. Ileal digestibility of dietary protein in the growing pig and adult human. Br J Nutr. 2009;102(12):1752-9. https://doi.org/10.1017/s00071145099912 67.

25. Boirie Y, Fauquant J, Rulquin H, Maubois JL, Beaufrere B. Production of large amounts of [13C]leucine-enriched milk proteins by lactating cows. J Nutr. 1995;125(1):92-8.

26. van Loon LJ, Boirie Y, Gijsen AP, Fauquant J, de Roos AL, Kies $\mathrm{AK}$, et al. The production of intrinsically labeled milk protein provides a functional tool for human nutrition research. J Dairy Sci. 2009;92(10):4812-22. https://doi.org/10.3168/jds.2009-2317.

27. van Vliet S, Beals JW, Parel JT, Hanna CD, Utterback PL, Dilger AC, et al. Development of intrinsically labeled eggs and poultry meat for use in human metabolic research. J Nutr. 2016;146(7):1428-33. https://doi.org/10.3945/jn.115.228338.

28. Biolo G, Tessari P, Inchiostro S, Bruttomesso D, Fongher C, Sabadin L, et al. Leucine and phenylalanine kinetics during mixed meal ingestion: a multiple tracer approach. Am J Physiol. 1992;262(4 Pt 1):E455-63. https://doi.org/10.1152/ajpendo.1992.262.4.e455.

29. Tang JE, Moore DR, Kujbida GW, Tarnopolsky MA, Phillips SM. Ingestion of whey hydrolysate, casein, or soy protein isolate: effects on mixed muscle protein synthesis at rest and following resistance exercise in young men. J Appl Physiol. 2009;107(3):987-92. https://doi.org/10.1152/japplphysiol.00076 .2009.

30. Reidy PT, Walker DK, Dickinson JM, Gundermann DM, Drummond MJ, Timmerman KL, et al. Protein blend ingestion following resistance exercise promotes human muscle protein synthesis. J Nutr. 2013;143(4):410-6. https://doi.org/10.3945/jn.112.16802 1jn.112.168021.

31. Gorissen SH, Horstman AM, Franssen R, Crombag JJ, Langer H, Bierau J, et al. Ingestion of wheat protein increases in vivo muscle protein synthesis rates in healthy older men in a randomized trial. J Nutr. 2016;146(9):1651-9. https://doi.org/10.3945/jn.116.23134 0 . 
32. Burd NA, Yang Y, Moore DR, Tang JE, Tarnopolsky MA, Phillips SM. Greater stimulation of myofibrillar protein synthesis with ingestion of whey protein isolate v. micellar casein at rest and after resistance exercise in elderly men. Br J Nutr. 2012;108(6):958-62. https://doi.org/10.1017/s0007114511006271.

33. Burd NA, Gorissen SH, van Vliet S, Snijders T, van Loon LJ. Differences in postprandial protein handling after beef compared with milk ingestion during postexercise recovery: a randomized controlled trial. Am J Clin Nutr. 2015;102(4):828-36. https://doi.org/10.3945/ajcn.114.103184.

34. Beals JW, Sukiennik RA, Nallabelli J, Emmons RS, van Vliet $\mathrm{S}$, Young JR, et al. Anabolic sensitivity of postprandial muscle protein synthesis to the ingestion of a protein-dense food is reduced in overweight and obese young adults. Am J Clin Nutr. 2016;104(4):1014-22. https://doi.org/10.3945/ajcn.116.13038 5.

35. van Vliet S, Shy EL, Abou Sawan S, Beals JW, West DW, Skinner $\mathrm{SK}$, et al. Consumption of whole eggs promotes greater stimulation of postexercise muscle protein synthesis than consumption of isonitrogenous amounts of egg whites in young men. Am J Clin Nutr. 2017;106(6):1401-12. https://doi.org/10.3945/ ajcn.117.159855.

36. Volpi E, Kobayashi H, Sheffield-Moore M, Mittendorfer B, Wolfe RR. Essential amino acids are primarily responsible for the amino acid stimulation of muscle protein anabolism in healthy elderly adults. Am J Clin Nutr. 2003;78(2):250-8.

37. Moughan JP. Holistic properties of foods: a changing paradigm in human nutrition. J Sci Food Agric. 2018. https://doi.org/10.1002/ jsfa.8997.

38. Jacobs DR Jr, Gross MD, Tapsell LC. Food synergy: an operational concept for understanding nutrition. Am J Clin Nutr. 2009;89(5):1543S-8S. https://doi.org/10.3945/ajen.2009.26736b.

39. Elliot TA, Cree MG, Sanford AP, Wolfe RR, Tipton KD. Milk ingestion stimulates net muscle protein synthesis following resistance exercise. Med Sci Sports Exerc. 2006;38(4):667-74. https:// doi.org/10.1249/01.mss.00002.

40. Gorissen SHM, Burd NA, Kramer IF, van Kranenburg J, Gijsen AP, Rooyackers O, et al. Co-ingesting milk fat with micellar casein does not affect postprandial protein handling in healthy older men. Clin Nutr. 2017;36(2):429-37. https://doi. org/10.1016/j.clnu.2015.12.011.

41. Gorissen SH, Burd NA, Hamer HM, Gijsen AP, Groen BB, van Loon LJ. Carbohydrate coingestion delays dietary protein digestion and absorption but does not modulate postprandial muscle protein accretion. J Clin Endocrinol Metab. 2014;99(6):2250-8. https://doi.org/10.1210/jc.2013-3970.

42. Churchward-Venne TA, Snijders T, Linkens AM, Hamer HM, van Kranenburg J, van Loon LJ. Ingestion of casein in a milk matrix modulates dietary protein digestion and absorption Kinetics but does not modulate postprandial muscle protein synthesis in older men. J Nutr. 2015;145(7):1438-45. https://doi.org/10.3945/ jn.115.213710.

43. Dhiman TR, Nam S-H, Ure AL. Factors affecting conjugated linoleic acid content in milk and meat. Crit Rev Food Sci Nutr. 2005;45(6):463-82. https://doi.org/10.1080/10408390591034463.

44. Smit LA, Baylin A, Campos H. Conjugated linoleic acid in adipose tissue and risk of myocardial infarction. Am J Clin Nutr. 2010;92(1):34-40. https://doi.org/10.3945/ajcn.2010.29524.

45. Farrell DJ. Enrichment of hen eggs with n-3 long-chain fatty acids and evaluation of enriched eggs in humans. Am J Clin Nutr. 1998;68(3):538-44.

46. Anderson KE. Comparison of fatty acid, cholesterol, and vitamin $\mathrm{A}$ and $\mathrm{E}$ composition in eggs from hens housed in conventional cage and range production facilities. Poult Sci. 2011;90(7):16008. https://doi.org/10.3382/ps.2010-01289.
47. Henchion M, Hayes M, Mullen AM, Fenelon M, Tiwari B. Future protein supply and demand: strategies and factors influencing a sustainable equilibrium. Foods. 2017. https://doi.org/10.3390/ foods6070053.

48. JanssenDuijghuijsen LM, van Norren K, Grefte S, Koppelman SJ, Lenaerts K, Keijer J, et al. Endurance exercise increases intestinal uptake of the peanut allergen ara $\mathrm{h} 6$ after peanut consumption in humans. Nutrients. 2017. https://doi.org/10.3390/nu9010084.

49. March DS, Marchbank T, Playford RJ, Jones AW, Thatcher R, Davison G. Intestinal fatty acid-binding protein and gut permeability responses to exercise. Eur J Appl Physiol. 2017;117(5):93141. https://doi.org/10.1007/s00421-017-3582-4.

50. Pugh JN, Impey SG, Doran DA, Fleming SC, Morton JP, Close GL. Acute high-intensity interval running increases markers of gastrointestinal damage and permeability but not gastrointestinal symptoms. Appl Physiol Nutr Metab. 2017;42(9):941-7. https:// doi.org/10.1139/apnm-2016-0646.

51. Karl JP, Margolis LM, Madslien EH, Murphy NE, Castellani JW, Gundersen Y, et al. Changes in intestinal microbiota composition and metabolism coincide with increased intestinal permeability in young adults under prolonged physiological stress. Am J Physiol Gastrointest Liver Physiol. 2017;312(6):G559-71. https://doi. org/10.1152/ajpgi.00066.2017.

52. Snipe RMJ, Khoo A, Kitic CM, Gibson PR, Costa RJS. Carbohydrate and protein intake during exertional heat stress ameliorates intestinal epithelial injury and small intestine permeability. Appl Physiol Nutr Metab. 2017;42(12):1283-92. https://doi. org/10.1139/apnm-2017-0361.

53. JanssenDuijghuijsen LM, Mensink M, Lenaerts K, Fiedorowicz E, Protégé Study Group, van Dartel DAM, et al. The effect of endurance exercise on intestinal integrity in well-trained healthy men. Physiol Rep. 2016. https://doi.org/10.14814/phy2.12994.

54. van Wijck K, Wijnands KA, Meesters DM, Boonen B, van Loon LJ, Buurman WA, et al. L-citrulline improves splanchnic perfusion and reduces gut injury during exercise. Med Sci Sports Exerc. 2014. https://doi.org/10.1249/mss.0000000000000332.

55. Van Wijck K, Lenaerts K, Van Bijnen AA, Boonen B, Van Loon $\mathrm{LJ}$, Dejong $\mathrm{CH}$, et al. Aggravation of exercise-induced intestinal injury by ibuprofen in athletes. Med Sci Sports Exerc. 2012;44(12):2257-62. https://doi.org/10.1249/mss.0b013e3182 $65 \mathrm{dd} 3 \mathrm{~d}$.

56. van Wijck K, Lenaerts K, van Loon LJ, Peters WH, Buurman WA, Dejong $\mathrm{CH}$. Exercise-induced splanchnic hypoperfusion results in gut dysfunction in healthy men. PLoS One. 2011;6(7):e22366. https://doi.org/10.1371/journal.pone.0022366.

57. Pals KL, Chang RT, Ryan AJ, Gisolfi CV. Effect of running intensity on intestinal permeability. J Appl Physiol. 1997;82(2):571-6. https://doi.org/10.1152/jappl.1997.82.2.571.

58. Oktedalen O, Lunde OC, Opstad PK, Aabakken L, Kvernebo K. Changes in the gastrointestinal mucosa after long-distance running. Scand J Gastroenterol. 1992;27(4):270-4.

59. Huang CY, Pai YC, Yu LC. Glucose-mediated cytoprotection in the gut epithelium under ischemic and hypoxic stress. Histol Histopathol. 2017;32(6):543-50. https://doi.org/10.14670/hh-11-839.

60. Miner-Williams WM, Stevens BR, Moughan PJ. Are intact peptides absorbed from the healthy gut in the adult human? Nutr Res Rev. 2014;27(2):308-29. https://doi.org/10.1017/s095442241 4000225.

61. Dever JT, Kemp MQ, Thompson AL, Keller HG, Waksmonski JC, Scholl CD, et al. Survival and diversity of human homologous dietary microRNAs in conventionally cooked top sirloin and dried bovine tissue extracts. PLoS One. 2015;10(9):e0138275. https:// doi.org/10.1371/journal.pone.0138275.

62. Zhang L, Hou D, Chen X, Li D, Zhu L, Zhang Y, et al. Exogenous plant MIR168a specifically targets mammalian LDLRAP1: 
evidence of cross-kingdom regulation by microRNA. Cell Res. 2012;22(1):107-26. https://doi.org/10.1038/cr.2011.158.

63. Izumi $\mathrm{H}$, Tsuda $\mathrm{M}$, Sato $\mathrm{Y}$, Kosaka $\mathrm{N}$, Ochiya $\mathrm{T}$, Iwamoto $\mathrm{H}$, et al. Bovine milk exosomes contain microRNA and mRNA and are taken up by human macrophages. J Dairy Sci. 2015;98(5):2920 33. https://doi.org/10.3168/jds.2014-9076.

64. Baier SR, Nguyen C, Xie F, Wood JR, Zempleni J. MicroRNAs are absorbed in biologically meaningful amounts from nutritionally relevant doses of cow milk and affect gene expression in peripheral blood mononuclear cells, HEK-293 kidney cell cultures, and mouse livers. J Nutr. 2014;144(10):1495-500. https:// doi.org/10.3945/jn.114.196436.

65. Moore DR, Tang JE, Burd NA, Rerecich T, Tarnopolsky MA, Phillips SM. Differential stimulation of myofibrillar and sarcoplasmic protein synthesis with protein ingestion at rest and after resistance exercise. J Physiol. 2009;587(Pt 4):897-904. https:// doi.org/10.1113/jphysiol.2008.164087.

66. Ertl P, Steinwidder A, Schönauer M, Krimberger K, Knaus W, Zollitsch W. Net food production of different livestock: a national analysis for Austria including relative occupation of different land categories/Netto-Lebensmittelproduktion der Nutztierhaltung: Eine nationale Analyse für Österreich inklusive relativer Flächenbeanspruchung. Die Bodenkultur J Land Manag Food Environ. 2016;67(2):91-103. https://doi.org/10.1515/boku-2016-0009.

67. Cervantes-Pahm SK, Stein HH. Ileal digestibility of amino acids in conventional, fermented, and enzyme-treated soybean meal and in soy protein isolate, fish meal, and casein fed to weanling pigs. J Anim Sci. 2010;88(8):2674-83. https://doi.org/10.2527/ jas.2009-2677.

68. Sarwar G. The protein digestibility-corrected amino acid score method overestimates quality of proteins containing antinutritional factors and of poorly digestible proteins supplemented with limiting amino acids in rats. J Nutr. 1997;127(5):758-64.

69. Ertl P, Knaus W, Zollitsch W. An approach to including protein quality when assessing the net contribution of livestock to human food supply. Animal. 2016;10(11):1883-9. https://doi. org/10.1017/s1751731116000902.

70. Rutherfurd SM, Fanning AC, Miller BJ, Moughan PJ. Protein digestibility-corrected amino acid scores and digestible indispensable amino acid scores differentially describe protein quality in growing male rats. J Nutr. 2015;145(2):372-9. https://doi. org/10.3945/jn.114.195438.

71. Abelilla JJ, Liu Y, Stein HH. Digestible indispensable amino acid score (DIAAS) and protein digestibility corrected amino acid score (PDCAAS) in oat protein concentrate measured in 20- to 30-kilogram pigs. J Sci Food Agric. 2018;98(1):410-4. https:// doi.org/10.1002/jsfa.8457.

72. Anyango JO, de Kock HL, Taylor JRN. Impact of cowpea addition on the Protein Digestibility Corrected Amino Acid Score and other protein quality parameters of traditional African foods made from non-tannin and tannin sorghum. Food Chemistry. 2011;124(3):775-80. https://doi.org/10.1016/j.foodc hem.2010.06.094.

73. Cervantes-Pahm SK, Liu Y, Stein HH. Digestible indispensable amino acid score and digestible amino acids in eight cereal grains. Br J Nutr. 2014;111(9):1663-72. https://doi.org/10.1017/s0007 114513004273.

74. Groen BBL, Horstman AM, Hamer HM, de Haan M, van Kranenburg J, Bierau J, et al. Post-prandial protein handling: you are what you just ate. PLoS One. 2015. https://doi.org/10.1371/journ al.pone. 0141582 .

75. Pennings B, Groen B, de Lange A, Gijsen AP, Zorenc AH, Senden $\mathrm{JM}$, et al. Amino acid absorption and subsequent muscle protein accretion following graded intakes of whey protein in elderly men. Am J Physiol Endocrinol Metab. 2012;302(8):E992-9. https://doi. org/10.1152/ajpendo.00517.2011.

76. Pennings B, Boirie Y, Senden JM, Gijsen AP, Kuipers H, van Loon LJ. Whey protein stimulates postprandial muscle protein accretion more effectively than do casein and casein hydrolysate in older men. Am J Clin Nutr. 2011;93(5):997-1005. https://doi. org/10.3945/ajcn.110.008102.

77. Yang Y, Breen L, Burd NA, Hector AJ, Churchward-Venne TA, Josse AR, et al. Resistance exercise enhances myofibrillar protein synthesis with graded intakes of whey protein in older men. Br J Nutr. 2012. https://doi.org/10.1017/s0007114511007422.

78. Robinson MJ, Burd NA, Breen L, Rerecich T, Yang Y, Hector AJ, et al. Dose-dependent responses of myofibrillar protein synthesis with beef ingestion are enhanced with resistance exercise in middle-aged men. Appl Physiol Nutr Metab. 2013;38(2):120-5. https://doi.org/10.1139/apnm-2012-0092.

79. Mitchell CJ, McGregor RA, D'Souza RF, Thorstensen EB, Markworth JF, Fanning AC, et al. Consumption of milk protein or whey protein results in a similar increase in muscle protein synthesis in middle aged men. Nutrients. 2015;7(10):8685-99. https://doi. org/10.3390/nu7105420.

80. Castellano BM, Thelen AM, Moldavski O, Feltes M, van der Welle RE, Mydock-McGrane L, et al. Lysosomal cholesterol activates mTORC1 via an SLC38A9-Niemann-Pick C1 signaling complex. Science. 2017;355(6331):1306-11. https://doi. org/10.1126/science.aag1417.

81. Yasuda M, Tanaka Y, Kume S, Morita Y, Chin-Kanasaki M, Araki $\mathrm{H}$, et al. Fatty acids are novel nutrient factors to regulate mTORC1 lysosomal localization and apoptosis in podocytes. Biochim Biophys Acta. 2014;1842(7):1097-108. https://doi.org/10.1016/j. bbadis.2014.04.001.

82. Salles J, Chanet A, Giraudet C, Patrac V, Pierre P, Jourdan M, et al. 1,25(OH)2-vitamin D3 enhances the stimulating effect of leucine and insulin on protein synthesis rate through $\mathrm{Akt} / \mathrm{PKB}$ and mTOR mediated pathways in murine $\mathrm{C} 2 \mathrm{C} 12$ skeletal myotubes. Mol Nutr Food Res. 2013;57(12):2137-46. https://doi. org/10.1002/mnfr.201300074.

83. Marzani B, Balage M, Venien A, Astruc T, Papet I, Dardevet $\mathrm{D}$, et al. Antioxidant supplementation restores defective leucine stimulation of protein synthesis in skeletal muscle from old rats. J Nutr. 2008;138(11):2205-11. https://doi.org/10.3945/ jn.108.094029.

84. Zhao Z, Barcus M, Kim J, Lum KL, Mills C, Lei XG. High dietary selenium intake alters lipid metabolism and protein synthesis in liver and muscle of pigs. J Nutr. 2016;146(9):1625-33. https://doi. org/10.3945/jn.116.229955.

85. Wade B, Cummins M, Keyburn A, Crowley TM. Isolation and detection of microRNA from the egg of chickens. BMC Res Notes. 2016;9:283. https://doi.org/10.1186/s13104-016-2084-5.

86. Miguel M, Aleixandre A. Antihypertensive peptides derived from egg proteins. J Nutr. 2006;136(6):1457-60. 